\title{
8 PROJETO DE PESQUISA: a inteligência emocional e espiritual em sala de aula
}

\author{
Ruy Cezar do Espirito Santo ${ }^{1}$ \\ Herminia Prado Godoy ${ }^{2}$ \\ Simone Andrade ${ }^{3}$
}

Lembramos que esse grupo de pesquisa se originou da necessidade de promover, estudar e estimular o autoconhecimento e a espiritualidade para profissionais de diferentes áreas e sobretudo na educação e com este objetivo desenvolvemos junto a CAPES, CNPq e PUC: a interdiciplinaridade, a espiritualidade e o autoconhecimento, vamos priorizar este ano o levar para sala de aula a prática da inteligência emocional e espiritual, sem deixar de desenvolver nossas linhas de pesquisas que tem como base os "momentos de transformação" delimitados por Espírito Santo em nossas últimas edições dessa revista.

Acreditamos que o autoconhecimento, bem como, o autocuidado e a espiritualidade perpassam pela temática da educação e poderiam ser trabalhados a partir de várias disciplinas. O homem é o único ser que não nasce pronto e que dispõe do livre arbítrio para a busca de sua plenitude. Assim, contemplamos o conceito de individuação criado pelo psicólogo Carl Gustav Jung, que é um processo pelo qual o ser humano evolui de um estado infantil de identificação para um estado de maior diferenciação, o que implica uma ampliação da consciência.

Objetivamos oferecer um despertar para a consciência do autoconhecimento, bem como, propiciar um espaço para educadores refletirem e vivenciarem o autoconhecimento e autocuidado. Acreditamos que o autoconhecimento, bem como, o autocuidado e a espiritualidade perpassam pela temática da educação e poderia ser trabalhado a partir de várias disciplinas.

O autoconhecimento pode ajudar a promover a busca do indivíduo em seus elementos básicos do dia a dia, por meio da observação de si e do outro, do conhecimento de seus limites, fraquezas, prazeres e necessidades reais.

\footnotetext{
${ }^{1}$ Ruy Cezar do Espírito Santo - coordenador do grupo INTERESPE e editor da ver Interespe. CV: http://lattes.cnpq.br/7857468452892458; Contato: ruycezar@terra.com.br

${ }^{2}$ Herminia Prado Godoy - pesquisadora do INTERESPE e editora executiva da revista INTERESPE. $\quad$ CV: $\quad \underline{\text { http://lattes.cnpq.br/1130515834292714; } \quad \text { E-mail: }}$ herminiagodoy@ymail.com

${ }^{3}$ Simone Moura Andrioli de Castro Andrade: pesquisadora do INTERESPE e membro do conselho editorial da revista INTERESPE. CV: http://lattes.cnpq.br/0618029679833651. Contato: simone50@terra.com.br
} 
Objetivamos criar um espaço de reflexões e transformações no qual os educadores possam trabalhar e englobar em suas práticas temas e metodologias que também propiciem uma melhor qualidade de vida para si e para seus alunos.

Para tanto elaboramos um projeto com a temática da inteligência emocional e espiritual em sala de aula.

Começaremos nosso projeto com um evento que realizaremos dia 22/08/2018 na PUCSP com a participação de nossa equipe tendo como público alvo os educadores.

Pretendemos que este seja o primeiro evento de uma série de muitos e contamos com a presença dos educadores em nossas reuniões mensais, e nos colocamos a disposição para reuniões e encontros a serem desenvolvidos nas próprias escolas da rede estadual, municipal e particular de ensino. 